\title{
Perancangan Kapal Tanpa Awak Penebar Pakan Ikan di Wilayah Pesisir Pantai Berbasis Microcontroller Arduino
}

\author{
Aknaf Sam Dabit ${ }^{1}$, Abdillah Ebriel Lianto ${ }^{1}$, Satrya Ady Branta ${ }^{1}$, Haris Nubli ${ }^{2}$, \\ Fajar Budi Laksono ${ }^{3}$, Aditya Rio Prabowo ${ }^{1}$, Nurul Muhayat ${ }^{1}$ \\ 1 Program Studi Teknik Mesin, Universitas Sebelas Maret, Surakarta, Indonesia \\ 2 Interdisciplinary Program of Marine Convergence Design, Pukyong National University, Busan, Korea Selatan \\ 3 Divisi Riset dan Teknik, DTECH-Engineering, Salatiga, Indonesia \\ e-mail address : aditya@ft.uns.ac.id
}

\begin{tabular}{|c|c|}
\hline Keywords: & Abstrak: (atau Abstract) \\
\hline $\begin{array}{l}\text { Unmanned Surface Vehicle } \\
\text { (USV), Ardunino Uno, } \\
\text { Arduino Due, sensor } \\
\text { ultrasonic }\end{array}$ & $\begin{array}{l}\text { Unmanned Surface Vehicle (USV) banyak digunakan di daerah maritim. Di } \\
\text { Indonesia ada banyak petani tambak ikan yang masih melakukan proses } \\
\text { pemberian pakan ikan secara manual menggunakan tenaga manusia. Untuk } \\
\text { pembudidaya ikan yang memiliki kolam } 10 \mathrm{~m} \times 4 \mathrm{~m} \text { atau lebih, hanya bisa } \\
\text { menabur pakan ikan di pinggir kolam, sehingga pakan ikan tidak bisa merata } \\
\text { hingga ke tengah kolam. Kapal tanpa awak penebar pakan ikan berbasis } \\
\text { microcontroller Arduino ini dibuat sebagai solusi untuk masalah petani ikan } \\
\text { yang memiliki ukuran kolam besar dalam distribusi pakan ikan lebih merata. } \\
\text { Dengan menggunakan kapal tanpa awak penebar pakan ikan berbasis } \\
\text { microcontroller Arduino pemberian pakan ikan akan lebih mudah, efisien, dan } \\
\text { merata. Tiga sensor ultrasonic yang terpasang dibagian depan kapal terhubung } \\
\text { dengan Arduino Due, yang dilanjutkan dengan melakukan paralel dengan } \\
\text { Arduino Uno yang mengatur pergerakan servo MG-995 untuk menggerakkan } \\
\text { daun kemudi kapal. Kapal dirancang mampu membawa beban pakan ikan } \\
\text { sebesar } 5 \text { kg dan mampu dioperasikan secara manual maupun otomatis. } \\
\text { Pengoperasian otomasi kapal dibantu dengan Arduino Uno dan Arduino Due } \\
\text { sebagai pusat pengaturan, dan tiga sensor ultrasonic memberi sinyal dengan } \\
\text { menangkap pengahalang didepan kapal, sehingga kapal mampu berbelok } \\
\text { sebelum terjadi tabrakan. }\end{array}$ \\
\hline
\end{tabular}

\section{PENDAHULUAN}

Unmanned Surface Vehicle (USV) dapat digunakan untuk berbagai jenis tugas dalam bidang aplikasi yang berbeda seperti intelijen pengawasan pantai, keamanan pelabuhan dan perbatasan, otonom pencarian, sinyal transmisi antara udara dan kendaraan bawah air, dan perlindungan kapal selam. Tujuan dibuatnya USV adalah untuk pengawasan laut maritime dan keselamatan area laut. Dalam beberapa tahun terakhir sistem kapal patroli sudah dibuat mengunakan konsep maritime supervision, yaitu konsep cerdas penggunaan kapal patroli laut tanpa awak [1]. Unmanned Surface Vehicle (USV) atau Autonomous Surface Vehicle (ASV) adalah kendaraan tak berawak yang beroperasi di permukaan air. USV telah digunakan untuk berbagai operasi militer sejak Perang Dunia Kedua [2].
Penelitian lapangan dilakukan di Desa Doplang, Klaten, Jawa Tengah. Hasil penelitian adalah masalah yang dihadapi oleh petani tambak ikan yang memiliki tambak dengan ukuran $\geq 10 \mathrm{~m} \times 4 \mathrm{~m}$ mengalami kesulitan pada saat melakukan proses pemberian pakan ikan hingga ketengah kolam. Dengan adanya permasalahan ini dibuatlah alat berupa kapal tanpa awak penebar pakan ikan dengan control otomatis dari microcontroller Arduino.

Penelitian kapal cepat penebar pakan ikan sebelumnya telah dilakukan oleh tim dosen dari Universitas Negeri Malang (UM), namun pada penelitian ini kapal cepat tanpa awak masih dikendalikan dengan menggunakan remote control. Dengan mengacu pada penelitian sebelumnya, pada penelitian ini dilakukan dengan menerapkan autonomous system dengan bantuan tiga sensor ultrasonic dan tiga microcontroller yaitu dua buah Arduino Uno dan satu buah Arduino Due guna menunjang sistem 
otomatis pada kapal. Daun kemudi kapal yang digerakkan oleh motor servo MG-995 akan secara otomatis berbelok ketika sensor ultrasonic menangkap sinyal penghalang didepannya dengan jarak $\pm 1 \mathrm{~m}$, dengan begitu kapal tidak mungkin menabrak penghalang didepannya.

Pada penelitian ini kami menggunakan jenis lambung katamaran. Lambung ini memiliki deck yang luas dengan tingkat stabilitas yang baik. Katamaran adalah tipe kapal yang memiliki dua buah lambung (twinhulls) yang dihubungkan oleh suatu konstruksi (bridge) sehingga menjadi sebuah kesatuan sebagai satu kapal. Struktur bridging adalah salah satu kelebihan kapal katamaran, karena mampu menambah tinggi bagian lambung timbul kapal (freeboard), sehingga kemungkinan terjadinya deck wetness lebih kecil [3]. Perahu dengan lambung katamaran berkembang pesat sebagai moda transportasi tidak hanya karena area deck yang luas tetapi juga karena kenyamanan dan keamanan stabilitasnya [4]

Konsep pengganda gaya dapat dicapai dengan menggunakan beberapa USV secara bersamaan. Misalnya, USV dapat dilengkapi dengan sistem sonar untuk mencari dan mencegah kemungkinan ancaman bawah laut di wilayah strategis. Penggandaan gaya ini juga sangat berguna untuk penelitian kelautan skala besar; misalnya, penggunaannya untuk survey lingkungan [5]

Dimensi lambung kapal memiliki panjang $=1000 \mathrm{~mm}$, lebar $=400 \mathrm{~mm}$, dan tinggi $=200$ mm. Untuk mendapatkan ukuran lambung kapal menggunakan acuan ukuran kapal patroli dengan tipe 19M Catamaran Fisheries Patrol Vessel (1C16108), dengan perbandingan 1:20, sedangkan tinggi kapal secara keseluruhan adalah tinggi lambung dan tangki pakan dengan desain mampu menampung $5 \mathrm{~kg}$ pakan ikan.

Sensor ultrasonic yang digunakan menggunakan tipe HC-SR04. Sensor ultrasonic adalah sensor yang berfungsi untuk merubah besaran fisis (suara) menjadi besaran listrik maupun sebaliknya yang dikonversi menjadi jarak. Konsep dasar dari sensor ini yaitu memanfaatkan prinsip pemantulan gelombang suara yang dapat diaplikasikan untuk menghitung jarak benda dengan frekuensi yang ditentukan sesuai dengan sumber oscilator. Disebut sebagai sensor ultrasonic dikarenakan sensor ini mengaplikasikan gelombang ultrasonic sebagai trandusernya yang memiliki frekuensi tinggi yaitu pada kisaran $20 \mathrm{kHz}$.

Reflektivitas gelombang ultrasonic pada permukaan benda padat hampir sama dengan reflektivitas suara ultrasonic dengan permukan benda cair. Meskipun begitu pada gelombang bunyi ultrasonic akan mudah diserap oleh bahan - bahan tertentu seperti bahan dari busa maupun tekstil [6].

\section{METODOLOGI PENELITIAN}

\subsection{Jenis Penelitian}

Penelitian ini adalah jenis penelitian survey. Data yang diperoleh didapat dari survey lapangan di Desa Doplang, Klaten, Jawa Tengah. Permasalahan hasil survey dibuat solusi berupa kapal tanpa awak penebar pakan ikan berbasis microcontroller Arduino. Dengan dibuatnya alat ini diharapkan mampu membantu para petani tambak ikan dalam pemberian pakan ikan secara otomatis dan merata.

\subsection{Perancangan Awal}

Pada tahap perancangan awal dilakukan penentuan motor penggerak, perhitungan displacement lambung kapal, dan kapasitas tangki pakan. Jenis motor yang dipilih adalah brushless motor, dengan alasan adalah daya tahan motor yang lebih lama dan putaran motor yang lebih stabil.

Tabel 1. Spesifikasi Motor Brushless

\begin{tabular}{|l|l|}
\hline \multicolumn{1}{|c|}{ Parameter } & \multicolumn{1}{|c|}{ Keterangan } \\
\hline Nama & $\begin{array}{l}\text { TOP EDGE 540 - 3660 } \\
\text { Inrunner Brushless Motor } \\
\text { KV 2730 }\end{array}$ \\
\hline Dimensi & $53 \mathrm{~mm} \times 145 \mathrm{~mm}$ \\
\hline Weight & $401 \mathrm{~g}$ \\
\hline $\mathrm{Kv}$ & $2730 \mathrm{rpm} / \mathrm{V}$ \\
\hline Tegangan & $7.4 \mathrm{v} 14.8 \mathrm{v}(2 \mathrm{~s} \sim 4 \mathrm{~s})$ \\
\hline Daya maksimum & $2600 \mathrm{watt}$ \\
\hline Working Current & $95 \mathrm{~A}$ \\
\hline Diameter shaft & $4,75 \mathrm{~mm}$ \\
\hline
\end{tabular}


Untuk mendapat berat total pada lambung kapal digunakan persamaan volume dan berat displacement lambung kapal. Persamaan volume displacement lambung kapal adalah sebagai berikut:

$$
\nabla=L W L \times B \times T \times C b
$$

Keterangan :

$$
\begin{array}{ll}
\Delta & =\text { Berat Displacement }(\mathrm{kg}) \\
L W L & =\text { Length Water Line }(\mathrm{m}) \\
B & =\text { Beam }(\mathrm{m}) \\
T & =\text { Draft }(\mathrm{m}) \\
C b & =\text { Coefisien Block }
\end{array}
$$

Persamaan berat displacement lambung kapal adalah sebagai berikut :

$$
\Delta=L W L \times B \times T \times C b \times \rho
$$

Keterangan :

$$
\begin{array}{ll}
\Delta & =\text { Berat Displacement }(\mathrm{kg}) \\
L W L & =\text { Length Water Line }(\mathrm{m}) \\
B & =\text { Beam }(\mathrm{m}) \\
T & =\text { Draft }(\mathrm{m}) \\
C b & =\text { Coefisien Block } \\
\rho & =\text { Massa Jenis Air }\left(\mathrm{kg} / \mathrm{m}^{3}\right)
\end{array}
$$

Persamaan luas permukaan lambung kapal adalah sebagai berikut :

$$
S=(C b \times B) \times(1.2 \times T)
$$

Keterangan :

$$
\begin{array}{ll}
S & =\text { Luas Permukaan }\left(m^{2}\right) \\
C b & =\text { Coefisien Block } \\
B & =\text { Beam }(\mathrm{m}) \\
T & =\text { Draft }(\mathrm{m})
\end{array}
$$

Persamaan tahanan total kapal adalah sebagai berikut :

$$
R T=C T \times 0,5 \times \rho_{\text {air tawar }} \times V s \times S
$$

Keterangan :

$$
\begin{array}{ll}
R T & =\text { Tahanan Total }(N) \\
C T & =\text { Coefisien Total } \\
V s & =\text { Kecepatan Kapal }(\mathrm{m} / \mathrm{s})
\end{array}
$$

$$
S \quad=\text { Luas Permukaan }\left(\mathrm{m}^{2}\right)
$$

Hasil perhitungan digunakan sebagai tolak ukur untuk mengetahui berat lambung kapal yang akan dibuat, dengan acuan ini maka akan bisa mengetahui pokok berat keseluruhan kapal yang akan digunakan untuk mendapat nilai daya yang dibutuhkan kapal untuk bergerak. Hasil perhitungan berat displacement lambung kapal diperoleh nilai sebesar $3,2 \mathrm{~kg}$. Hasil data lambung kapal akan diperlihatkan pada Tabel 2 dibawah ini.

Tabel 2. Data Lambung Kapal

\begin{tabular}{|l|l|l|}
\hline Nama Perhitungan & \multicolumn{1}{|c|}{ Simbol } & \multicolumn{1}{c|}{ Nilai } \\
\hline Length Over All & LOA & $1 \mathrm{~m}$ \\
\hline Beam & $B$ & $0,1 \times 2 \mathrm{~m}$ \\
\hline Dept & $D$ & $0,2 \mathrm{~m}$ \\
\hline Draft & $T$ & $0,08 \mathrm{~m}$ \\
\hline Coefisien Block & Cb & 0,2 \\
\hline $\begin{array}{l}\text { Volume } \\
\text { Displacement }\end{array}$ & $\nabla$ & $0,0032 \mathrm{~m}^{3}$ \\
\hline Berat Displacement & $\Delta$ & $3,2 \mathrm{~kg}$ \\
\hline Luas Permukaan & $S$ & $0,136 \mathrm{~m}^{2}$ \\
\hline Tahanan Total & $R T$ & $1,37 \mathrm{~N}^{2}$ \\
\hline
\end{tabular}

Hasil perhitungan dibuat acuan untuk mendapatkan nilai daya minimal yang diperlukan oleh kapal untuk mampu bergerak. Perhitungan daya kapal dijelaskan pada persamaan dibawah ini :

$$
P=\Sigma \text { massa } \times S f \times v_{\text {kapal }}
$$

Keterangan :

$$
\begin{array}{ll}
P & =\text { Daya }(\mathrm{HP}) \\
\Sigma \text { massa } & =\text { Jumlah Beban }(\mathrm{kg}) \\
S f & =\text { Safety Factor } \\
v_{\text {kapal }} & =\text { Kecepatan Kapal }(\mathrm{m} / \mathrm{s})
\end{array}
$$

Hasil perhitungan daya yang dibutuhkan kapal untuk bergerak adalah sebesar $0.53 \mathrm{HP}$, nilai ini sangat kecil dikarenakan kapal tidak membutuhkan putaran yang kencang, sehingga dengan pemilihan brushless motor tipe TOP EDGE 540 - 3660 sudah sangat mencukupi kebutuhan penggerak kapal.

Pada tahap selanjutnya adalah perencanaan kapasitas tangki pakan ikan. Berdasarkan hasil survey 
yang dilakukan, didapat data kebutuhan pakan ikan harian sebesar $5 \mathrm{~kg}$. Dari data tersebut dirancang sebuah tangki pakan berbentuk balok dengan ukuran $500 \mathrm{~mm} \times 200 \mathrm{~mm} \times 200 \mathrm{~mm}$, sehingga diperoleh ukuran kapasitas tangki pakan sebesar $8,57 \mathrm{~kg}$. Ukuran tangki ini sengaja dilebihkan setinggi $82 \mathrm{~mm}$ untuk pembatas pakan ikan supaya tidak jatuh keluar saat kapal sedang ber-maneuver.

\subsection{Pembuatan Desain}

Tahap ini adalah tahap realisasi bentuk kapal yang dibuat dalam bentuk gambar 3D. Pembuatan desain kapal dilakukan dengan bantuan software Solidwork Premium 2017. Semua ukuran kapal mengacu pada hasil perhitungan yang telah dilakukan pada tahap sebelumnya. Pada tahap ini juga akan diperlihatkan komponen apa saja yang mendukung terwujudnya kapal tanpa awak penebar pakan ikan berbasis microcontroller Arduino ini. Setiap komponen didesain terlebih dahulu sebelum nantinya direalisakan. Hasil desain kapal akan diperlihatkan pada Gambar 3 dibawah ini.

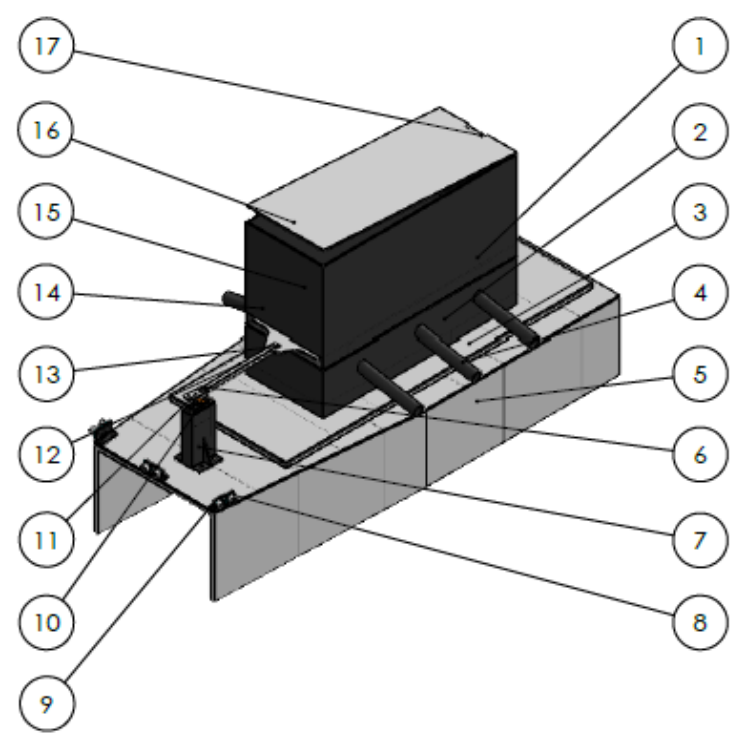

Gambar 3. Desain Kapal Tanpa Awak Penebar Pakan Ikan Berbasis Microcontroller Arduino

Komponen pendukung kapal antara lain adalah sebagai berikut :

1. Tangki Pakan Ikan

2. Dudukan Pipa Pakan

3. Dudukan Tangki Pakan
4. Pipa Pakan
5. Lambung Kapal
6. Mur Baut M4
7. Dudukan Servo
8. Sensor Ultrasonic HCSR04
9. Tempat Sensor Ultrasonic
10. Servo MG995
11. Tuas Servo
12. Tuas Penggerak Papan Geser
13. Ball Bearing ISO195 OD $13 \mathrm{~mm}$
14. Papan Geser Tangki Pakan
15. Slider Single
16. Tutup Tangki Pakan
17. Engsel

\subsection{Perancangan Sistem}

Pada tahap ini akan dijelaskan mengenai apa saja perangkat keras yang diperlukan untuk menjalankan sistem otomatis kapal, metode cara pengolahan coding untuk menjalankan kapal supaya dapat bekerja sesuai dengan apa yang diinginkan. Beberapa kebutuhan perangkat keras kapal adalah sebagai berikut :

1. Ardunio Uno 2 Buah

2. Arduino Due

3. Relay 4 Channel

4. Baterai Li-Po 3S

5. Sensor Ultrasonic HC-SR04 3 Buah

6. Baterai Rechargeable 4 Buah

7. Remote Control

8. Receiver

9. Motor Servo MG-995 2 Buah

10. Electronic Speed Control (ESC)

11. Brushless Motor TOP EDGE 540

12. Breadboard 2 Buah

Proses perancangan sistem elektronika kapal yang terintegrasi dengan komponen penggerak kapal sebagai komponen utama pada kapal akan dijabarkan pada Gambar 4 berbentuk diagram blok dibawah ini : 


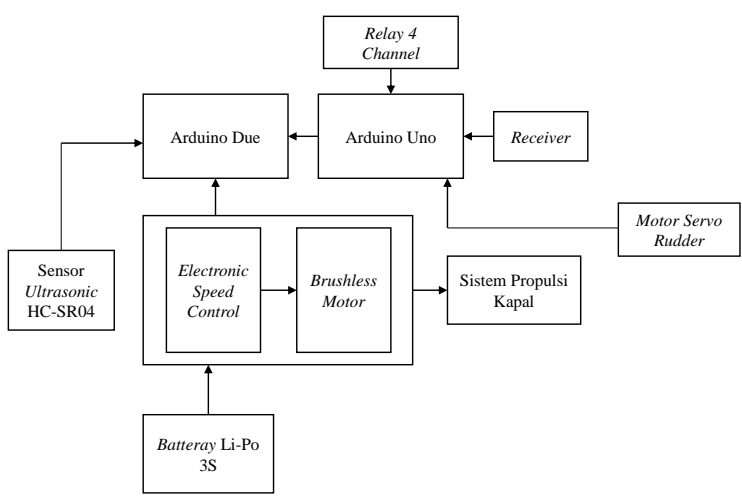

Gambar 4. Diagram Blok Sistem Otomatis Kapal

Selain perancangan sistem otomatis kapal, ada juga perancangan sistem elektronika untuk mengatur buka tutup tangki pakan ikan secara otomatis. Sistem buka tutup tangki pakan ikan akan diperlihatkan pada Gambar 5 berbentuk diagram blok dibawah ini :

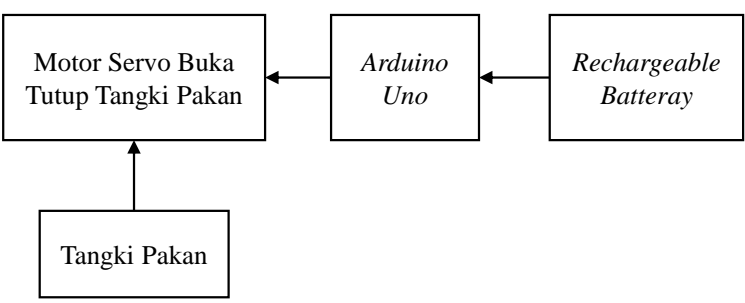

Gambar 5. Diagram Blok Sistem Otomatis Buka Tutup Pakan Ikan

\subsection{Implementasi Program Otomatis}

Pada tahap ini akan dijelaskan mengenai apa tahapan-tahapan untuk merancang sebuah program untuk menjalankan perintah otomatis kapal di dalam microcontroller Arduino Uno dan Arduino Due. Sebelum melakukan tahap pembuatan program atau biasa disebut proses coding, maka perlu diketahui terlebih dahulu bagaimana alat ini nantinya bekerja. Perencanaan gerakan kapal tanpa awak penebar pakan ikan berbasis microcontroller Arduino melakukan pemberian pakan ikan setiap 10 detik sekali. Dalam gerakannaya kapal akan bergerak secara bebas, namun ketika sensor ultrasonic membaca adanya penghalang didepannya dengan jarak \pm 1 $\mathrm{m}$, maka sensor ultrasonic akan mengirimkan data kepada Arduino Due untuk diproses dan memerintahkan motor servo untuk membelokkan rudder kekiri atau kekanan tergantung sensor ultrasonic mana yang mendapat sinyal tersebut, diperintahkan untuk berbelok sebesar $45^{\circ}$. Pembuatan program Arduino Uno dan Arduino
Due menggunakan bahasa pemrograman jenis $\mathrm{C}++$ yang disederhanakan, biasa disebut bahasa sketch. Diagram alir fungsi kerja bahasa pemrograman pada Arduino secara umum akan ditampilkan pada Gambar 6 dibawah ini :

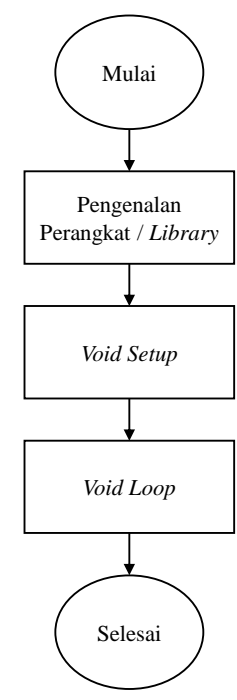

Gambar 6. Diagram Alir Fungsi Kerja Pemrograman Arduino

Diagram alir diatas menjelaskan serangkaian sistem pembacaan atau pengolahan bahasa pemrograman didalam Arduino Board. Setiap perangkat yang tersambung kepada arduino harus mempunyai tanda pengenal atau biasa disebut dengan library. Fungsi dari library ini sendiri adalah akses utama program perintah yang akan ketikan didalam Arduino mampu tersampaikan secara pasti kepada perangkat yang telah dikenali library-nya. Tanpa adanya sebuah library pada perangkat yang ingin dituju program, maka hasil program tidak bisa di upload. Telah tersedia banyak jenis library perangkat keras pada Arduino itu sendiri, seperti contoh meliputi sensor, motor servo, relay dan lain-lain. Setelah pengenalan perangkat, selanjutnya adalah proses void setup. Void setup sendiri berisi perintah yang dilakukan hanya sekali dalam rangkaian kerja sistem didalam pengoperasian perangkat keras oleh Arduino. Void setup biasanya berisi tentang nilai besaran nilai PWM dan juga input pin perangkat elektronik pada Arduino board dengan nilai tunggal. Setelah program selesai pada void setup, program memasuki proses terakhir yaitu void loop. Perintah di dalam script program Arduino 
yang telah dibuat nantinya akan diproses secara berulang secara trus-menerus didalam void loop ini. Pada void loop ini program berulang berjalan.

Pemrograman didalam Arduino Uno dan Due meliputi tiga program pokok yang digunakan untuk mengatur arah gerak dan perintah pemberian pakan pada kapal tanpa awak penebar pakan ikan berbasis microcontroller Arduino ini. Program tersebut adalah sebagai berikut :

1. Pemrograman Buka Tutup Tangki Pakan

2. Pemrograman Relay

3. Pemrograman Sensor Ultrasonic dan Motor

Pada pemrograman buka tutup pakan ikan perangkat pendukung yang digunakan adalah satu buah Arduino Uno dan motor servo MG-995 dengan kekuatan beban sebesar $12 \mathrm{~kg}$. Pengolahan program Arduino Uno mengacu pada lama bukaan tangki pakan ikan untuk mengeluarkan pakan ikan yang melewati enam pipa jalur keluaran pakan ikan dengan diameter $20 \mathrm{~mm}$. Pengaturan waktu lama bukaan tangki pakan ikan adalah 1 detik. Setetelah 1 detik, tangki pakan ikan kembali menutup. Nilai delay yang digunakan adalah 1000 microsecond, dimana nilai ini menunjukan lama waktu selama 1 detik. Posisi awal motor servo berada pada posisi $90^{\circ}$. Dengan jarak lama waktu antara bukaan satu dengan bukaan yang lain adalah selama 10 detik. Setelah 10 detik, motor servo bergerak CCW sebesar $145^{\circ}$, kemudian kembali pada posisi $90^{\circ}$ ketika bukaan sudah mencapai waktu 1 detik. Perintah ini akan bekerja secara terus menerus, hingga pakan ikan yang berada didalam tangki pakan telah habis. Sehingga ketika pakan dirasa sudah tidak keluar, maka kapal sudah selesai menyelesaikan tugasnya. Library yang digunakan untuk akses pengenalan motor servo MG-995 pada Arduino Uno adalah <Servo.h> dengan inisial motorServo. Perintah void setup adalah (motorServo.attach (7); // servo pada pin digital 7). Skema bentuk buka tutup tangki pakan ikan akan diperlihatkan pada Gambar 7 dibawah ini.

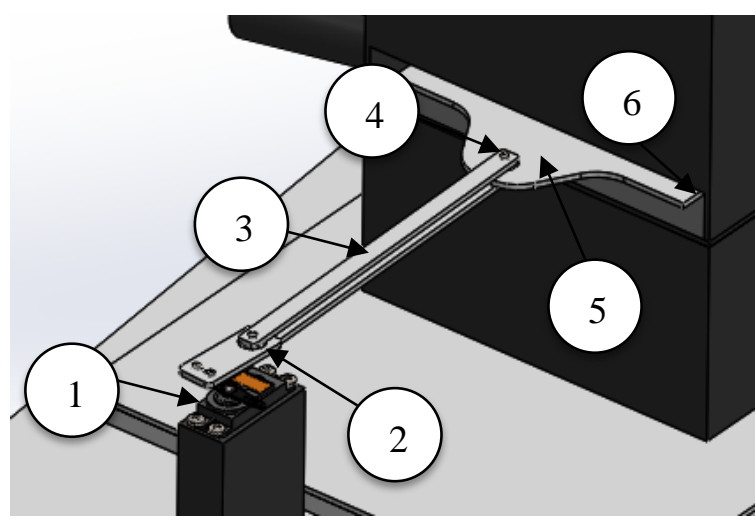

Gambar 7. Skema Buka Tutup Tangki Pakan Ikan

Komponen pendukung kapal antara lain adalah sebagai berikut :

1. Motor Servo MG-995

2. Tuas Servo

3. Tuas Papan Geser

4. Ball Bearing OD $13 \mathrm{~mm}$

5. Papan Geser Pakan Ikan

6. Slider Single $45 \mathrm{~mm}$

Bentuk penampang tangki pakan ikan akan diperlihatkan pada Gambar 8 dibawah ini.

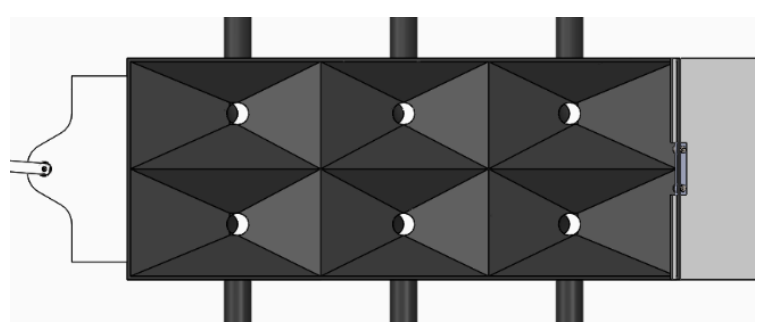

Gambar 8. Penampang Tangki Pakan Ikan

Selanjutnya adalah pemrograman relay dan motor. Fungsi kerja relay adalah sebagai saklar otomatis untuk menghidupkan dan mematikan program otomatis kapal. Relay yang digunakan adalah relay 4 channel, relay ini tersambung oleh receiver remote control dan Arduino Uno pada kapal. Sinyal yang diberikan oleh potensio meter dari remote control melewati receiver berbentuk pulsa yang mana disebut Pulse Width Modulation (PWM). Pulsa ini akan memberi sinyal untuk proses berpindahnya high channel dan low channel pada relay, nilai inilah yang menjadi acuan untuk ON/OFF sistem otomatis pada kapal. Library yang digunakan pada relay yang tersambung pada receiver adalah $<$ ch1> digunakan untuk nilai pulsa pada receiver. 
Program input pin pada relay didalam Arduino Uno dibagi menjadi dua untuk nilai PWM yang masuk yaitu pada ch $1<1400$ maka relay dalam keadaan OFF, dan nilai PWM pada ch1>1400 maka relay dalam keadaan ON. Nilai PWM pada relay akan dijelaskan pada Tabel 3 dan Tabel 4 dibawah ini.

Tabel 3. Nilai PWM ch1<1400 Relay (OFF)

\begin{tabular}{|l|c|}
\hline \multicolumn{1}{|c|}{ Nilai } & Input Pin \\
\hline digitalWrite $($ High $)$ & 3 \\
\hline digitalWrite $($ Low $)$ & 4 \\
\hline digitalWrite $($ Low $)$ & 7 \\
\hline digitalWrite $($ High $)$ & 5 \\
\hline
\end{tabular}

Tabel 4. Nilai PWM ch1>1400 Relay $(\mathrm{ON})$

\begin{tabular}{|l|c|}
\hline \multicolumn{1}{|c|}{ Nilai } & Input Pin \\
\hline digitalWrite (Low) & 3 \\
\hline digitalWrite (High) & 4 \\
\hline digitalWrite (High) & 7 \\
\hline digitalWrite (Low) & 5 \\
\hline
\end{tabular}

Perintah void setup yang digunakan untuk menjalankan program ON/OFF relay akan dijelaskan pada Tabel 5 dibawah ini.

Tabel 5. Void Setup Relay

\begin{tabular}{|l|c|}
\hline \multicolumn{1}{|c|}{ Initial } & Input Pin dan Nilai \\
\hline pinMode & 3 \\
\hline pinMode & 4 \\
\hline pinMode & 7 \\
\hline pinMode & 5 \\
\hline Serial.begin & 9600 \\
\hline
\end{tabular}

Program selanjutnya adalah pemrograman sensor ultrasonic. Sensor ultrasonic yang digunakan berjumlah tiga buah, dengan tipe HCSR04. Setiap sensor ultrasonic terhubung secara langsung dengan Arduino Due sebagai pengolah program yang diberikan berupa sinyal suara yang ditangkap oleh sensor. Sensor ultrasonic melemparakan sinyal suara untuk mendeteksi halangan yang berada didepannya. Posisi terbaik untuk memancarkan sinyal dan menerima sinyal kembali adalah sejajar dengan penghalang. Sinyal ini nantinya akan diolah oleh Arduino Due berbentuk satuan jarak $(\mathrm{mm})$ untuk diteruskan menjadi gerakan motor servo yang digunakan untuk menggerakkan rudder kapal. Library yang digunakan pada pemrograman ini ada dua yaitu <Ultrasonic.h> untuk tanda pengenal sensor ultrasonic, dan library <Servo.h> untuk tanda pengenal motor servo MG-995 dan juga brushless motor. Library <Servo.h> dibagi menjadi dua lagi yaitu (motorServo;) untuk tanda pengenal motor servo MG-995 dan (motorServo 2;) untuk tanda pengenal brushless motor. Void setup untuk pin input motor servo MG-995 dan brushless motor akan ditunjukan pada Tabel 6 dibawah ini.

Tabel 6. Void Setup Library <motorServo>

\begin{tabular}{|l|c|}
\hline \multicolumn{1}{|c|}{ Initial } & Input Pin dan Nilai \\
\hline motorServo.attach & 2 \\
\hline motorServo.attach 2 & 3 \\
\hline SerialUSB.begin & 9600 \\
\hline
\end{tabular}

\section{HASIL PENGUJIAN}

Pengujian dilakukan untuk membuktikan apakah program dan perhitungan yang telah dibuat sebelumnya mampu bekerja sesuai yang diinginkan dan tepat secara teori. Pengujian program dan perhitungan akan meliputi uji buoyancy lambung kapal, uji sensor ultrasonic HC-SR04, dan uji kemampuan pemberian pakan ikan

\subsection{Hasil Uji Bouyancy Lambung Kapal}

Pengujian bouyancy adalah pengujian lambung kapal dengan tujuan untuk mengetahui daya apung lambung kapal dengan cara memasukan lambung kapal di air kemudian melakukan pengamatan terhadap lambung kapal, apakah lambung kapal seimbang atau tidak. Hasil uji bouyancy lambung ditampilkan pada Tabel 7 diabawah ini.

Tabel 7. Hasil Uji Bouyancy Lambung Kapal

\begin{tabular}{|l|l|}
\hline \\
Gambar 9. Uji Bouyancy Lambung Kapal
\end{tabular}




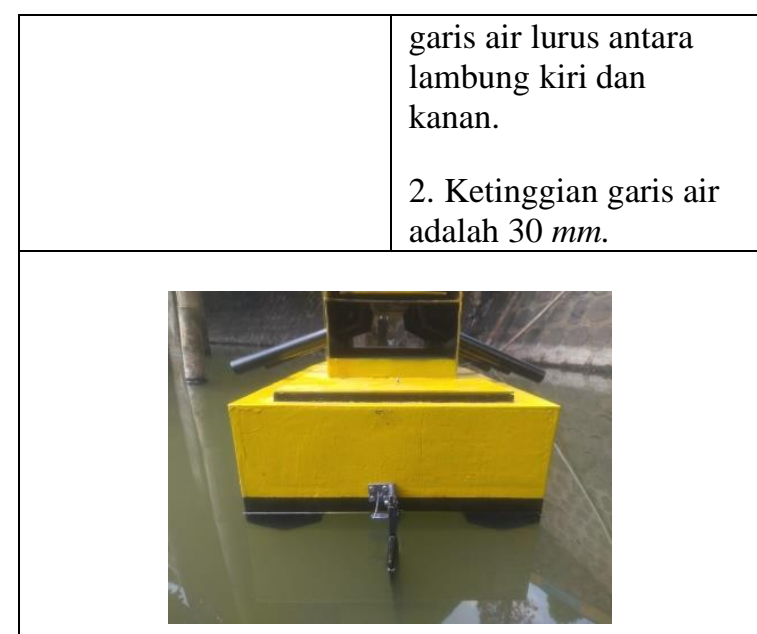

Gambar 10. Uji Bouyancy Kapal Keseluruhan

\begin{tabular}{|l|l|}
\hline Jenis Pengujian & Hasil Pengujian \\
\hline $\begin{array}{l}\text { Uji Bouyancy Kapal } \\
\text { Keseluruhan }\end{array}$ & $\begin{array}{l}\text { 1. Bouyancy / d } \\
\text { apung lambung } \\
\text { seimbang. Terli } \\
\text { garis air lurus a } \\
\text { lambung kiri dan } \\
\text { kanan. } \\
\text { 2. Ketinggian } \\
\text { adalah 60 mm. }\end{array}$ \\
\hline
\end{tabular}

Gambar 11. Uji Bouyancy Keseluruhan Kapal Dengan Beban $5 \mathrm{~kg}$

\begin{tabular}{|l|l|}
\hline Jenis Pengujian & Hasil Pengujian \\
\hline $\begin{array}{l}\text { Kesi Bouyancy } \\
\text { Dengan Beban 5 kg }\end{array}$ & $\begin{array}{l}\text { 1. Bouyancy / daya } \\
\text { apung lambung } \\
\text { seimbang. Terlihat } \\
\text { garis air lurus dengan } \\
\text { garis batas air pada } \\
\text { kapal (Length Water } \\
\text { Line) }\end{array}$ \\
& $\begin{array}{l}\text { 2. Ketinggian garis air } \\
\text { adalah } 80 \text { mm. }\end{array}$ \\
& $\begin{array}{l}\text { 3. Batas daya angkut } \\
\text { kapal terhadap pakan } \\
\text { ikan adalah 5 kg, } \\
\text { terlihat dari Gambar } 4.4 \\
\text { bahwa garis air telah } \\
\text { menyentuh batas }\end{array}$ \\
\hline
\end{tabular}

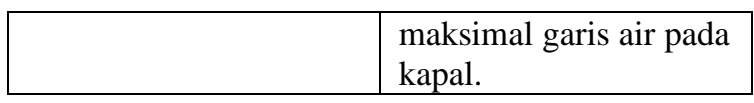

\subsection{Hasil Uji Sensor Ultrasonic}

Pengujian program sensor ultrasonic HCSR04 dilakukan dengan melakukan serial monitor terlebih dahulu pada Arduino IDE, dan dipastikan dapat berjalan dengan baik. Pengujian ini dilakukan untuk mengetahui apakah sensor ultrasonic dapat membaca jarak yang diteruskan dengan gerakan servo rudder. Hasil uji program sensor ultrasonic HC-SR04 ditampilkan pada Tabel 8 dibawah ini.

Tabel 8. Hasil Uji Sensor Ultrasonic

\begin{tabular}{|c|c|}
\hline Tahap Pengujian & Hasil Pengujian \\
\hline Tahap 1 Jarak $100 \mathrm{~cm}$ & $\begin{array}{l}\text { 1. Respon sensor } \\
\text { ultrasonic HC-SR04 } \\
\text { dengan benda } \\
\text { penghalang adalah } \\
\text { setelah benda bergerak } \\
\text { pada jarak } 55 \mathrm{~cm} \text {. } \\
\text { 2. Keakuratan } \\
\text { pembacaan sensor pada } \\
\text { jarak } 100 \mathrm{~cm} \text { berkurang } \\
\text { sejauh } 45 \mathrm{~cm} \text {. }\end{array}$ \\
\hline Tahap 2 Jarak $55 \mathrm{~cm}$ & $\begin{array}{l}\text { 1. Respon sensor } \\
\text { ultrasonic HC-SR04 } \\
\text { dengan benda } \\
\text { penghalang adalah } \\
\text { setelah benda bergerak } \\
\text { pada jarak } 49,7 \mathrm{~cm} \text {. } \\
\text { 2. Keakuratan } \\
\text { pembacaan sensor pada } \\
\text { jarak } 55 \mathrm{~cm} \text { berkurang } \\
\text { sejauh } 5.3 \mathrm{~cm} \text {. }\end{array}$ \\
\hline Tahap 3 Jarak 49,7 cm & $\begin{array}{l}\text { 1. Respon sensor } \\
\text { ultrasonic HC-SR04 } \\
\text { dengan benda } \\
\text { penghalang adalah } \\
\text { setelah benda bergerak } \\
\text { pada jarak } 49,7 \mathrm{~cm} \text {. } \\
\text { 2. Keakuratan } \\
\text { pembacaan sensor pada } \\
\text { jarak } 49,7 \mathrm{~cm} \text { tepat. }\end{array}$ \\
\hline
\end{tabular}

\subsection{Hasil Uji Kemampuan Pemberian Pakan Ikan}

Uji kemampuan pemberian pakan ikan ini dilakukan dengan tujuan untuk mengetahui keluaran pakan ikan dari tangki pakan pada setiap detiknya. Metode yang dilakukan adalah dengan melakukan pencataan waktu selama 1 
detik ketika papan geser pakan ikan dibuka. Pakan yang keluar ditampung kemudian dilakukan penimbangan pakan ikan yang telah keluar selama 1 detik. Pengukuran dilakukan selama tiga kali bukaan pakan ikan. Metode pengujian kemampuan pemberian pakan ikan ditampilkan pada Tabel 9 dibawah ini.

Tabel 9. Hasil Uji Kemampuan Pemberian Pakan

\begin{tabular}{|l|l|}
\hline \multicolumn{1}{|c|}{ Tahap Pengujian } & \multicolumn{1}{c|}{ Hasil Pengujian } \\
\hline Tahap 1 & $\begin{array}{l}\text { 1. Keluaran pakan ikan } \\
\text { sebanyak 0.36 kg } \\
\text { 2. Lama waktu bukaan } \\
\text { tangki pakan ikan } \\
\text { adalah 1 detik }\end{array}$ \\
\hline Tahap 2 & $\begin{array}{l}\text { 1. Keluaran pakan ikan } \\
\text { sebanyak 0.29 kg }\end{array}$ \\
& $\begin{array}{l}\text { 2. Lama waktu bukaan } \\
\text { tangki pakan ikan } \\
\text { adalah 1 detik }\end{array}$ \\
\hline Tahap 3 & $\begin{array}{l}\text { 1. Keluaran pakan ikan } \\
\text { sebanyak 0.21 kg }\end{array}$ \\
& $\begin{array}{l}\text { 2. Lama waktu bukaan } \\
\text { tangki pakan ikan } \\
\text { adalah 1 detik }\end{array}$ \\
\hline
\end{tabular}

\section{KESIMPULAN}

Dari hasil pengujian hasil program kapal tanpa awak penebar pakan ikan berbasis microcontroller Arduino, maka dapat diambil kesimpulan sebagai berikut :

1. Kapal tanpa awak penebar pakan ikan berbasis microcontroller Arduino memanfaatkan tiga sensor ultrasonic yang terpasang didepan kapal untuk mengatur gerakan daun kemudi (rudder) ketika akan terjadi tabrakan dengan pembatas kolam dengan jarak $\pm 1 \mathrm{~m}$.

2. Sistem otomatis kapal diatur melewati remote control dengan memutar potensio meter pada remote control untuk mengatur ON/OFF pada relay 4 channel.

3. Pemrograman otomatis kapal diatur oleh dua microcontroller yaitu Arduino Uno dan Arduino Due.

4. Pemrograman buka tutup tangki pakan ikan setiap 10 detik sekali diatur oleh satu Arduino Uno yang terhubung langsung dengan motor servo MG-995.

5. Tingkat keakuratan sensor ultrasonic HC-SR04 hanya sebesar $49.7 \mathrm{~cm}$. Dengan begitu perlu digunakan jenis sensor pendeteksi jarak lain untuk meningkatkan kerja kapal.

6. Tingkat kemampuan pemberian pakan ikan selama tuga kali bukaan adalah $0.36 \mathrm{~kg}, 0.29 \mathrm{~kg}$, dan $0.21 \mathrm{~kg}$.

\section{REFERENSI}

[1] M. Zhu, Y.Q. Wen, "Design and Analysis of Collaborative Unmanned Surface- Aerial Vehicle Cruise Systems." Journal of Advanced Transportation, 2019.

[2] D. Hardianto, W.D. Aryawan, "Pembuatan Konsep Desain Unmanned Surface Vehicle (USV) untuk Monitoring Wilayah Perairan Indonesia." Jurnal Teknik ITS, Institute Technology Sepuluh Nopember, Surabaya, Indonesia vol. 6, pp. 2337 - 3520, 2017.

[3] M. A. Luhur, W. Amirudin, dan E. S. Hadi, "Analisis Perbedaan Performa Pada Kapal Ikan Dengan Mengubah Bentuk Monohull Menjadi Katamaran.” Jurnal Teknik Perkapalan, vol. 5, no. 1, pp. 113-119, 2017.

[4] M.S. Seif, E. Amini, "Performance Comparison Between Planing Monohull and Catamaran at High Froude Numbers." Iranian Journal of Science and Technology vol. 28, pp. 435 - 441, 2004.

[5] K. Tanakitkorn, "A review of unmanned surface vehicle development." Maritime Technology and Research, Kasersart University, Chonburi, Thailand, vol. 1, pp. 1-7, 2019.

[6] Siswanto, I. Rojikin, dan W. Gata, "Pemanfaatan Sensor Suhu DHT-22, Ultrasonik HC-SR04 Untuk Mengendalikan Kolam Dengan Notifikasi Email," Jurnal Rekayasa Sistem dan Teknologi Informasi, vol. 1, no. 1, pp. 544-551, 2017. 